\title{
Tемтинескии резале
}

Т ЭМАТЫЧНЫ РАЗДЗЕЛ

\section{Special topic SEction}

\author{
100-летие Рижского мирного договора \\ 100-годдзе Рыжскага мірнага дагавора \\ $100^{\text {th }}$ anniversary of the Riga Treaty
}

УДК 930:327.5((47+57)+438)«1919-1920»:327((47+57)+438)(094.2)«1921»:930:329.15(47+57)

\section{ПРОБАЕМАТИКА ПОАЬСКО-СОВЕТСКОЙ ВОЙНЫ 1919-1920 гГ. И РИЖСКОГО МИРНОГО АОГОВОРА В ОТРАЖЕНИИ ПРОТОКОЛОВ ЗАСЕААНИИ ПОАИТБЮРО ЦК РКП(б)}

\author{
H. H. $M E 3 \Gamma A^{1)}$ \\ ${ }^{1)}$ Гомельский государственный университет им. Францииска Скорины, \\ ул. Советская, 104, 246019, г. Гомель, Беларусь
}

Определена роль проблематики польско-советской войны и Рижского мирного договора в деятельности Политбюро ЦК РКП(б). Установлено, что в 1919 г. эти вопросы занимали незначительное место в работе политбюро, польско-советскому противостоянию отводилась второстепенная роль на фоне борьбы большевиков с Белым движением. Протоколы политбюро 1920 г. отражают рост значения польского фронта для советской России, но и в этих условиях вопросы польско-советской войны не стали доминирующими в деятельности политбюро. Наибольшее внимание оно уделяло вопросам пропагандистской работы, а также подготовки и хода мирных переговоров с Польшей летом - осенью 1920 г.

\section{Образец цитирования:}

Мязга ММ. Праблематыка польска-савецкай вайны 1919-1920 гг. і Рыжскага мірнага дагавора ў адлюстраванні пратаколаў пасяджэнняў Палітбюро ЦК РКП(б). Часопіс Беларускага дзяржаўнага ўніверсітэта. Гісторыя. 2021;2:7-16.

https://doi.org/10.33581/2520-6338-2021-2-7-16
For citation:

Miazga MM. Problems of the Polish-Soviet war of 1919-1920 and the Riga Treaty in reflection of the RCP(b) Central Committee Politburo minutes of meetings. Journal of the Belarusian State University. History. 2021;2:7-16. Belarusian. https://doi.org/10.33581/2520-6338-2021-2-7-16

\section{Aв тор:}

Николай Николаевич Мезга - доктор исторических наук, профессор; заведующий кафедрой всеобщей истории исторического факультета.

\section{Author:}

Mikalai M. Miazga, doctor of science (history), full professor; head of the department of general history, faculty of history. nmezga@gsu.by 
Материалы заседаний политбюро подтверждают, что именно этот партийный орган принимал решения по ключевым вопросам польско-советских отношений, которые затем реализовывались советской дипломатией. Белорусский вопрос во время польско-советской войны рассматривался политбюро крайне редко и лишь в контексте достижения советской Россией ее внешнеполитических целей.

Ключевые слова: польско-советская война; Рижский мирный договор; Политбюро ЦК РКП(б); советская Россия; Польша; польско-советские отношения; мирные переговоры.

Благодарность. Статья подготовлена в рамках выполнения задания государственных программ научных исследований на 2021-2025 гг.

\title{
ПРАБАЕМАТЫКА ПОАЬСКА-САВЕЦКАЙ ВАЙНЫ 1919-1920 ГГ. I РЫЖСКАГА МІРНАГА ААГАВОРА Ў АААЮСТРАВАННІ ПРАТАКОААЎ ПАСЯАЖЭННЯЎ ПААІТБЮРО ЦК РКП(б)
}

\author{
М. М. МязГА ${ }^{1^{*}}$ \\ 1* Гомельскі дзяржаўны ўніверсітэт імя Францыска Скарыны, \\ вул. Савецкая, 104, 246019, г. Гомель, Беларусь
}

\begin{abstract}
Акрэслена роля праблематыкі польска-савецкай вайны і Рыжскага мірнага дагавора ў дзейнасці Палітбюро ЦК РКП(б). Устаноўлена, што ў 1919 г. гэтыя пытанні займалі нязначнае месца ў працы палітбюро, польска-савецкаму супрацьстаянню адводзілася другарадная роля на фоне барацьбы бальшавікоў з Белым рухам. Пратаколы палітбюро 1920 г. адлюстроўваюць рост значэння польскага фронту для Савецкай Расіi, але і ў гэтых умовах праблема польска-савецкай вайны не стала дамінуючай у дзейнасці палітбюро. Найбольшую ўвагу яно надавала пытанням прапагандысцкай працы, а таксама падрыхтоўкі і ходу мірных перамоў з Польшчай летам - восенню 1920 г. Матэрыялы пасяджэнняў палітбюро пацвярджаюць, што менавіта гэты партыйны орган прымаў рашэнні па ключавых пытаннях польска-савецкіх адносін, якія затым рэалізоўваліся савецкай дыпламатыяй. Беларускае пытанне ў час польска-савецкай вайны разглядалася палітбюро вельмі рэдка і толькі ў кантэксце дасягнення Савецкай Расіяй яе знешнепалітычных мэт.
\end{abstract}

Ключавыя словы: польска-савецкая вайна; Рыжскі мірны дагавор; Палітбюро ЦК РКП(б); Савецкая Расія; Польшча; польска-савецкія адносіны; мірныя перамовы.

Падзяка. Артыкул падрыхтаваны ў рамках выканання задання дзяржаўных праграм навуковых даследаванняў на 2021-2025 гг.

\section{PROBLEMS OF THE POLISH-SOVIET WAR OF 1919-1920 AND THE RIGA TREATY IN REFLECTION OF THE RCP(b) CENTRAL COMMITTEE POLITBURO MINUTES OF MEETINGS}

\author{
M. M. MIAZGA \\ ${ }^{\mathrm{a}}$ Francisk Skorina Gomel State University, 104 Savieckaja Street, Homiel 246019, Belarus
}

The role of the problems of the Polish-Soviet war and the Riga Treaty in the activities of the Politburo of the RCP(b) Central Committee is revealed. It is established that in 1919 this problem occupied an insignificant place in the work of the Politburo, the Polish-Soviet confrontation was given a secondary role against the background of the struggle of the Bolsheviks with the White Movement. The protocols of the Politburo of 1920 reflect the growing importance of the Polish front for Soviet Russia. But even in these circumstances, the issues of the Polish-Soviet war did not become dominant in the activities of the Politburo. It paid the greatest attention to the issues of propaganda work and the preparation and progress of peace negotiations with Poland in the summer and autumn of 1920. The materials of the Politburo meetings confirm that it was this party body that made decisions on key issues of Polish-Soviet relations, which were then implemented by Soviet diplomacy. The Belarusian question during the Polish-Soviet war was considered by the Politburo very rarely and only in the context of Soviet Russia's achievement of its foreign policy goals.

Keywords: Polish-Soviet war; Riga Treaty; Politburo of the RCP(b) Central Committee; Soviet Russia; Poland; Polish-Soviet relations; peace negotiations.

Acknowledgements. The article is prepared within the framework of the state research programs task for 2021-2025. 


\section{Уводзіны}

Польска-савецкая вайна і падпісанне Рыжскага мірнага дагавора, якім яна завяршылася, з'яўляюцца падзеямі, што прадвызначылі многія гістарычныя працэсы на беларускіх землях на працягу ўсяго міжваеннага перыяду. У час гэтай вайны Беларусь была полем узброенай барацьбы паміж Савецкай Расіяй і Польшчай. У ходзе канфлікту вырашалася пытанне аб дамінаванні ва Усходняй Еўропе, і Беларусь выступала як адзін з аб’ектаў гэтай барацьбы. Асноўныя рашэнні, якія непасрэдна датычыліся Беларусі, прымаліся палітычнымі лідарамі іншых краін. Яны зыходзілі з уласных міжнародна-палітычных інтарэсаў. У гэтым артыкуле зроблена спроба вызначыць месца праблематыкі польска-савецкай вайны і мірных перамоў у Мінску і Рызе ў дзейнасці Палітбюро ЦК РКП(б). Устаноўлена ступень значнасці ўказанай праблематыкі для вышэйшага кіраўніцтва РКП(б), зыходзячы з інтэнсіўнасці яе абмеркавання на пасяджэннях палітбюро, выяўлены тыя яе аспекты, якім бальшавіцкія лідары надавалі найбольшую ўвагу. Вывучэнне матэрыялаў, звязаных 3 дзейнасцю палітбюро, дазваляе больш поўна зразумець механізм прыняцця рашэнняў, што вызначалі знешнюю палітыку Савецкай Расіі ва ўмовах вайны 3 Польшчай.

Асноўнымі гістарычнымі крыніцамі для дасягнення пастаўленай мэты даследавання сталі матэрыялы фонду 17 «Цэнтральны Камітэт КПСС (ЦК КПСС) (1898, 1903-1991 гг.)» Расійскага дзяржаўнага архіва сацыяльна-палітычнай гісторыі. Шэраг гісторыкаў у сваіх працах выкарыстоўваюць матэрыялы гэтага архіва, у тым ліку і фонду 17 (гл. даследаванні Г. Матвеева [1], Д. Кораткавай [2], I. Міхуцінай [3], У. Снапкоўскага [4], Р. Лазько [5], В. Бароўскай [6], В. Зубачэўскага [7]). Але работа па сістэмным вывучэнні рашэнняў Палітбюро ЦК РКП(б), якія датычыліся польска-савецкай вайны, на сёння яшчэ далёкая да завяршэння.

\section{Вынікі і іх абмеркаванне}

У сярэдзіне лютага 1919 г. пачаліся ваенныя дзеянні паміж Чырвонай арміяй і Войскам польскім. Аднак праблемы польска-савецкага фронту ў парадку дня працы Палітбюро ЦК РКП(б) з’явіліся толькі уу канцы красавіка. Не будзе памылкай звязаць гэта 3 канчатковай стратай бальшавікамі Вільні. Так, 26 красавіка палітбюро абмяркоўвала факт падрыву польскімі дыверсантамі двух чыгуначных мастоў на ўсход ад Мінска. У прынятай пастанове ставілася задача ўзмацніць ахову мастоў, адказным за выкананне рашэння прызначаўся I. Сталін ${ }^{1}$. Па прапанове Л. Троцкага 29 красавіка палітбюро прыняло рашэнне аб ліквідацыі двайнога падначалення армій на заходнім фронце. Гэта азначала, што будзе ліквідавана фармальная самастойнасць Беларуска-Літоўскай арміi ${ }^{2}$.

Як сведчаць матэрыялы палітбюро, становішча савецкіх войск на польскім фронце было не самым лепшым. На сумесным пасяджэнні палітбюро і арганізацыйнага бюро 22 мая 1919 г. абмяркоўвалася пытанне баяздольнасці арміі. Ужо сама фармулёўка пытання («...аб усіх непарадках на гэтым фронце і неабходнасці ўзмацніць работу»³) утрымлівае адмоўную ацэнку становішча на заходнім фронце. Але, па сутнасці, для паляпшэння становішча прадугледжвалася толькі адна мера - накіраванне на ўмацаванне фронту камуністаў. У якасці «рэвізора» на заходні фронт камандзіраваўся І. Смілга. 3 рашэнняў палітбюро бачна, што чакалася далейшае адступленне савецкіх войск на заходнім напрамку, бо планавалася стварэнне брыгад чыгуначнікаў, задача якіх заключалася ў падрыве мастоў і разбурэнні чыгуначных пуцей ${ }^{4}$.

3 дакументаў палітбюро вынікае, што фронт 3 Польшчай не разглядаўся вышэйшым кіраўніцтвам бальшавіцкай партыі як адзін 3 найбольш важных. Яскрава пра гэта сведчыць рашэнне палітбюро ад 1 чэрвеня 1919 г., калі была адобрана дырэктыва, якая прадпісвала «зняць 3 заходняга фронту ўсё магчымае, скараціўшы да мінімуму ўсе актыўныя дзеянні». Знятыя войскі планавалася перакінуць у Данбас супраць арміі Дзянікіна ${ }^{5}$ Стаўленне да польска-савецкага фронту як да другараднага не змянілася і восенню 1919 г. Палітбюро ў сваім рашэнні ад 15 кастрычніка адзначала, што пытанне аб паўночным і заходнім франтах павінна разглядацца толькі «з пункта гледжання бяспекі Маскоўска-Тульскага раёна ў першую чаргу, Петраграда - у другую чаргу». Зноў ставілася задача зняць войскі з заходняга фронту, каб накіраваць іх супраць Дзянікіна 6.

На сумесным пасяджэнні палітбюро і аргбюро 2 чэрвеня была заслухана справаздача I. Смілгі аб яго паездцы на польскі фронт. Па выніках справа-

\footnotetext{
${ }^{1}$ Рос. гос. арх. соц.-полит. истории (РГАСПИ). Ф. 17. ОП. 3. Д. 4 [Электронный ресурс]. URL: http://sovdoc.rusarchives.ru/sections/government//cards/56632/images (дата обращения: 10.12.2020).

${ }_{2}^{2}$ Там же. Д. 6. URL: http://sovdoc.rusarchives.ru/sections/government//cards/56632/images (дата обращения: 10.12.2020).

${ }^{3}$ Тут і далей пераклад наш. - M. M.

${ }_{5}^{4}$ РГАСПИ. Д. 8. URL: http://sovdoc.rusarchives.ru/sections/government//cards/56681/images (дата обращения: 10.12.2020).

${ }^{5}$ Там же. Д. 10. URL: http://sovdoc.rusarchives.ru/sections/government//cards/56695/images (дата обращения: 10.12.2020).

${ }^{6}$ Там же. Д. 31. URL: http://sovdoc.rusarchives.ru/sections/government//cards/56847/images (дата обращения: 10.12.2020).
} 
здачы прынялі рашэнне перш за ўсё аб кадравым умацаванні заходняга фронту. Ставілася задача знайсці кандыдатаў на пасады камандарма і члена Рэвалюцыйнага ваеннага савета (РBC) БеларускаЛітоўскай арміі. Таксама планавалася папоўніць гэту армію 5-6 тыс. прызыўнікоў першай чаргі, а таксама за кошт новай мабілізацыі прафесійных саюзаў. I. Смілгу зноў камандзіравалі ў БеларускаЛітоўскую армію для ўпарадкавання яе дзейнасці. На гэтым жа пасяджэнні было прынята рашэнне аб карэннай рэарганізацыі заходняга фронту, што прадугледжвала і ліквідацыю фармальна самастойных армій нацыянальных савецкіх рэспублік, у тым ліку Беларуска-Літоўскай арміi. Усе войскі цяпер павінны былі падпарадкоўвацца непасрэдна галоўнаму камандаванню расійскай Чырвонай арміiі ${ }^{7}$ Тым самым даводзілася да лагічнага завяршэння рашэнне палітбюро, прынятае яшчэ 29 красавіка, у адпаведнасці з якім Беларуска-Літоўская армія была рэарганізавана ў 16-ю армію [8, с. 114].

Летам у парадку дня палітбюро з'яўляецца пытанне магчымага мірнага ўрэгулявання канфлікту з Польшчай. Гэта можна звязаць 3 тым, што ў Белавежскай пушчы пачыналіся перамовы Ю. Мархлеўскага 3 прадстаўнікамі Ю. Пілсудскага. Народны камісарыят замежных спраў РСФСР 27 чэрвеня прадставіў у Палітбюро ЦК РКП(б) праект урэгулявання спрэчных тэрытарыяльных пытанняў паміж Савецкай Расіяй і Польшчай. У дачыненні да Беларусі ў праекце ўказвалася, што да ліку магчымых уступак не можа адносіцца ачышчэнне савецкімі войскамі занятых «беларускіх мясцовасцей, гэта значыць Мінскай губ. і Дзіснянскага і Вілейскага паветаў (Віленскай губ.)» [9, с. 323].

У жніўні - верасні 1919 г. палітбюро звярнулася да гуманітарных аспектаў у адносінах з Польшчай. У прыватнасці, 16 жніўня была прынята прапанова Г. Чычэрына аб згодзе пачаць перамовы 3 палякамі аб заложніках. У той жа час было вырашана зацягваць абмен місіямі Чырвонага Крыжа ${ }^{8}$. Палітбюро вярнулася да гэтага пытання 6 верасня. Канстатавалася, што польскі ўрад даў згоду на прыезд дэлегацыі расійскага Чырвонага Крыжа. Яе кіраўніком быў зацверджаны Ю. Мархлеўскі ${ }^{9}$. Пры гэтым 2 лістапада бакі падпісалі пагадненне аб заложніках. Згодна 3 ім вызваляліся і накіроўваліся ў Польшчу арыштаваныя ў савецкіх рэспубліках палякі [10, с. 35]. Але фактычна Ю. Мархлеўскі пад прыкрыццём місіі Чырвонага Крыжа накіроўваўся для перамоў з прадстаўнікамі Ю. Пілсудскага ў Мікашэвічах. Палітбюро абмеркавала ход перамоў 14 лістапада. Л. Троцка- му і Г. Чычэрыну даручалася «распрацаваць дэталёва ўмовы перамір'я з палякамі». Умовы палякаў, якія перадаў Ю. Мархлеўскі, лідары бальшавікоў палічылі прымальнымі, за выключэннем пункта аб спыненні ўзброенай барацьбы з Пятлюрам. Савецкае кіраўніцтва пагаджалася з патрабаваннем палякаў аб таемнасці перамоў ${ }^{10}$. Як справядліва адзначае расійскі даследчык Г. Матвееў, 1919 г. стаў для савецкай улады самым цяжкім за ўвесь час вайны, таму бальшавікі былі гатовы на любыя тэрытарыяльныя ўступкі Польшчы за кошт нерасійскіх тэрыторый, абы толькі завяршыць канфлікт з ёй [1, с. 33], што і праявілася ў час перамоў у Мікашэвічах.

Вопіс 3 фонду 17 Расійскага дзяржаўнага архіва сацыяльна-палітычнай гісторыі ўтрымлівае матэрыялы аб 51 пасяджэнні Палітбюро ЦК РКП(б) у 1919 г. Толькі на 11 пасяджэннях абмяркоўваліся пытанні, якія мелі дачыненне да польска-савецкай вайны. Гэта дазваляе зрабіць выснову, што дадзеная праблема мела невысокую значнасць для вышэйшага савецкага кіраўніцтва. Акрэсліваліся меры, якія павінны былі спрыяць павышэнню баяздольнасці заходняга фронту, але іх цяжка прызнаць значнымі. Закраналіся пытанні дасягнення мірнага ўрэгулявання канфлікту з Польшчай.

У 1920 г. фронт з Польшчай ператварыўся ў адзін з галоўных для Савецкай Расіі. Гэта адразу адбілася на інтэнсіўнасці абмеркавання палітбюро пытанняў польска-савецкай вайны i ix змесце. У сувязі з гэтым 27 лютага адбыўся абмен тэлеграмамі паміж У. Леніным і Л. Троцкім. Два бальшавіцкія лідары прыйшлі да высновы, што існуе рэальная пагроза аднаўлення вайны 3 Польшчай [12, с. 280-281]. Пасля гэтага 28 лютага палітбюро паставіла задачу накіраваць на заходні фронт усіх палякаўкамуністаў $з$ іншых франтоў і ўнутраных губерняў. Прадпісвалася прадаставіць у распараджэнне польскага бюро пры ЦК РКП(б) «усе неабходныя матэрыяльныя сродкі для падтрымкі руху ў Польшчы». К. Радэку даручалася кіраўніцтва «ўсёй друкаванай агітацыяй і азнаямленне грамадскай думкі з пазіцыяй Расіі і польскага ўрада ў польскім пытанні, каб вайна, якая можа ўзнікнуць $з$ Польшчай, была правільна зразумета рускімі і польскімі масамі як нападзенне імперыялістычнай Польшчы ва ўгоду Антанце на жадаючую міру Савецкую Расію» ${ }^{11}$. Як бачна, лічачы цалкам верагодным пачатак актыўных дзеянняў на Польскім фронце, палітбюро надзвычай вялікае значэнне надавала таму, каб прадставіць Савецкую Расію ў вачах грамадскасці

${ }^{7}$ РГАСПИ. Ф. 17. ОП. 3. Д. 11 [Электронный ресурс]. URL: http://sovdoc.rusarchives.ru/sections/government//cards/56697/images (дата обращения: 10.12.2020).

${ }^{8}$ Там же. Д. 21. URL: http://sovdoc.rusarchives.ru/sections/government//cards/56764/images (дата обращения: 10.12.2020).

${ }^{9}$ Там же. Д. 25. URL: http://sovdoc.rusarchives.ru/sections/government//cards/56794/images (дата обращения: 10.12.2020).

${ }^{10}$ Там же. Д. 38. URL: http://sovdoc.rusarchives.ru/sections/government//cards/56922/images (дата обращения: 10.12.2020).

${ }^{11}$ Там же. Д. 63. URL: http://sovdoc.rusarchives.ru/sections/government//cards/57155 (дата обращения: 13.12.2020). 
як бок, які абараняецца. Таксама рабілася стаўка на аслабленне Войска польскага праз актыўную прапагандысцкую работу з удзелам польскіх камуністаў.

Важнае значэнне ў барацьбе з Польшчай надавалася дзеянням партызан. Так, 8 сакавіка 1920 г. палітбюро разгледзела пытанне аб мэтазгоднасці пачатку партызанскага руху ў Літве і Беларусі. У прынятым рашэнні адзначалася, што «разгортванне партызанскіх выступленняў у межах Тарыбскай Літвы і польскай акупацыі» прызнавалася «крайне пажаданым» ${ }^{12}$.

Ва ўмовах набліжэння новай фазы вайны з Польшчай заходні фронт меў патрэбу ў папаўненнях. Па гэтым пытанні 17 красавіка палітбюро прыняло пастанову, у якой указвалася, што тыя падмацаванні, якія накіроўваюцца на заходні фронт, складаюцца ў значнай частцы $з$ сялян, якія раней ухіляліся ад мабілізацыі. Таму для павышэння баяздольнасці заходняга фронту ставілася задача накіраваць на яго «значную колькасць рабочых камуністаў». у пастанове падкрэслівалася таксама неабходнасць «у значна большай меры, чым гэта зроблена да цяперашняга часу, сканцэнтраваць увагу партыйных арганізацый і шырокіх рабочых мас на польскім фронце». Партыйныя арганізацыі павінны былі ўзмацніць ваенную прапаганду і накіраваць пэўную частку работнікаў на польскі фронт. Перад палітычным упраўленнем Чырвонай арміі ставілася задача адправіць на заходні фронт ваенных палітработнікаў з іншых франтоў і тылу. Таксама прадугледжваліся меры па забеспячэнні заходняга фронту харчаваннем ${ }^{13}$. Такім чынам, для ўмацавання баяздольнасці заходняга фронту палітбюро першаснае значэнне надавала ўмацаванню яго бальшавіцкімі і рабочымі кадрамі.

Наступны раз палітбюро звярнулася да праблематыкі польска-савецкай вайны 28 красавіка, калі ўжо разгортвалася польскае наступленне на ўкраінскіх землях. К. Радэку і Л. Троцкаму даручалася сфармуляваць тэзісы аб неабходнасці праяўлення «максімальнага напружання партыйных, агітацыйных і іншых сіл на заходнім фронце», а таксама напісаць «маніфест да рускага народа». Давалася распараджэнне прызначыць «неабходных асоб для кіраўніцтва агітацыяй» ${ }^{14}$. У гэты ж дзень палітбюро адобрыла стратэгічны план ваенных дзеянняў супраць Польшчы. Прадугледжвалася, што галоўны ўдар Чырвоная армія нанясе ў Беларусі сіламі заходняга фронту. Паўднёва-заходні фронт павінен быў наступаць у напрамку Роўна - Брэст. Яго планавалася ўзмацніць Першай коннай арміяй $[10$, c. $52-53]$.
На пасяджэнні палітбюро 4 мая абсалютная большасць пытанняў парадку дня была прысвечана польска-савецкай вайне. У першую чаргу, як і на пасяджэнні 28 красавіка, намячаліся мерапрыемствы агітацыйнага характару. Польскае наступленне на Кіеў у тыя дні развівалася паспяхова. На выпадак здачы горада планавалася спыніць «на паўгадзіны работу ўсіх заводаў, устаноў і г. д. і правесці лятучыя мітынгі, прысвечаныя польскаму наступленню». Саўнаркам павінен быў на працягу 12 гадзін знайсці «папяровыя сродкі для абслугоўвання агітацыі». Губернскім і павятовым выканкамам даручалася перадрукаваць маніфест саўнаркама аб вайне з Польшчай і распаўсюдзіць яго па ўсіх валасцях, вёсках. Маніфест і агітацыйная літаратура аб вайне 3 Польшчай павінны былі максімальна шырока распаўсюджвацца сярод сялянства. Паўсюдна планавалася правесці валасныя сходы, на якіх трэба было зачытаць маніфест. Чакаліся выступленні У. Леніна, Л. Троцкага, Л. Каменева на тэму вайны 3 Польшчай. У сваіх прамовах бальшавіцкія лідары павінны былі характарызаваць польскае наступленне як «абломкі плана інтэрвенцыі, які праваліўся», указаць на парушэнне правоў «самавызначанай Украінскай Рэспублікі» (Беларусь у гэтым кантэксце не прыгадваецца). Неабходна было рабіць акцэнт на тым, што Савецкая Расія з'яўляецца бокам, які абараняецца. Для таго каб прадставіць Польшчу як агрэсара, што парушае ўзятыя на сябе абавязацельствы, планавалася абнародаваць інфармацыю аб патаемных перамовах Ю. Мархлеўскага 3 палякамі летам і восенню 1919 г. і дасягнутых на іх дамоўленасцях. Для арганізацыі адпору палякам Л. Троцкі мусіў адправіцца ў паездку на заходні фронт. Пры палітычным упраўленні Чырвонай арміi стваралася камісія для кіраўніцтва агітацыяй на польскім фронце. Палітбюро зацвердзіла рашэнне «польскай канферэнцыі аб мабілізацыі ўсіх камуністаў-палякаў, якія з'яўляюцца прыгоднымі для фронту». Было вырашана надрукаваць ліст генерала Брусілава, у якім выказвалася падтрымка савецкаму ўраду ў вайне 3 Польшчай. Гэтым крокам бальшавікі разлічвалі прыцягнуць да барацьбы тых, хто не з'яўляўся іх прыхільнікам, але быў гатовы адстойваць у змаганні з палякамі «расійскія» тэрыторыі ${ }^{15}$. Як адзначае Г. Матвееў, у дадзеным рашэнні палітбюро гучалі нязвыклыя для бальшавікоў патрыятычныя ноткі [11, с. 37]. Шмат увагі надаючы разгортванню прапагандысцкай работы, палітбюро не пакідала без увагі і ваеннае уммацаванне заходняга фронту. Так, 6 мая было прынята рашэнне аб паскарэнні перакідкі войск

\footnotetext{
${ }^{12}$ РГАСПИ. Ф. 17. Оп. 3. Д. 65 [Электронный ресурс]. URL: http://sovdoc.rusarchives.ru/sections/government//cards/57185/images (дата обращения: 13.12.2020).

${ }^{13}$ Там же. Д. 70. URL: http://sovdoc.rusarchives.ru/sections/government//cards/57242/images (дата обращения: 13.12.2020).

${ }^{14}$ Там же. Д. 73. URL: http://sovdoc.rusarchives.ru/sections/government//cards/57284/images (дата обращения: 13.12.2020).

${ }^{15}$ Там же. Д. 74. URL: http://sovdoc.rusarchives.ru/sections/government//cards/13305/childs (дата обращения: 13.12.2020).
} 
3 каўказскага фронту на польскі. Адказным за гэту справу прызначаўся І. Сталін ${ }^{16}$.

У наступныя дні палітбюро прыняло рашэнні аб кадравым умацаванні польскага фронту высокапастаўленымі партыйнымі работнікамі. А. Чарвякова пакінулі ў распараджэнні заходняга фронту ${ }^{17}$. Рашэннем ад 10 мая на ўмацаванне польскага фронту накіроўваліся Пятакоў, Смілга, Сакольнікаў, Мяснікоў, Мархлеўскі і Радэк ${ }^{18}$. У далейшым палітбюро працягвала працу па кадравым умацаванні савецкіх войск на заходнім напрамку. У прыватнасці, 18 мая І. Сталін быў прызначаны членам РВС паўднёва-заходняга фронту ${ }^{19}$. На пасяджэнні 8 чэрвеня палітбюро вырашыла накіраваць на заходні фронт Разенгольца (у якасці члена 15-й арміi), Грынштэйна і Аляксандрава (у распараджэнне РВС фронту). Аргбюро даручалася паскорыць накіраванне «адказных работнікаў са складу савецкіх і партыйных устаноў Масквы» на заходні фронт. У якасці папаўнення для фронту планавалася адправіць рабочых тых прадпрыемстваў, якія спынялі сваю работу ${ }^{20}$. Дадзеныя рашэнні адлюстроўвалі актыўную падрыхтоўку да наступлення войск Чырвонай арміі ў Беларусі.

На пасяджэнні 10 мая былі вызначаны новыя крокі па ўзмацненні прапагандысцкай работы на польскім фронце. Ставілася задача «намеціць польскага камуніста, агітатара і літаратара, для складання злабадзённых адозваў». Палітбюро прыняло рашэнне прапанаваць паэту Дзям'яну Беднаму накіравацца на заходні фронт для «літаратурнаагітацыйнай палітычнай работы». А вось ад ідэі адпраўкі на заходні фронт агітацыйнага цягніка палітбюро адмовілася 3-за транспартных цяжкасцей. Для кіраўніцтва агітацыйнай работай у прыфрантавой паласе стваралася часовае Бюро ЦК РКП(б). Мянжынскі павінен быў узмацніць асобы аддзел заходняга фронту «шляхам перакідкі туды работнікаў 3 іншых месцаў» ${ }^{21}$. У рамках разгортвання прапагандысцкай кампаніi 15 чэрвеня палітбюро вырашыла падрыхтаваць маніфест да польскіх салдат, які павінна была прыняць сесія УЦВК [13, с. 121].

Паспяховае польскае наступленне ва Украіне падштурхнула бальшавікоў да пошуку саюзнікаў супраць Польшчы. Яшчэ 4 мая палітбюро абмеркавала ліст члена РВС заходняга фронту I. Уншліхта аб адносінах да «беларускіх левых эсэраў». Іх вырашылі выкарыстаць для «работы ў тыле праціўніка» ${ }^{22}$. Гэта было невыпадковым. Даследаванні беларускіх гісторыкаў паказваюць, што прыкладна палова партызанскіх атрадаў на тэрыторыі Беларусі ў той час знаходзіліся пад кіраўніцтвам бальшавікоў, а другую частку ўзначальвалі беларускія эсэры [8, с. 122]. Палітбюро зноў звярнулася да беларускага пытання 25 мая ў сувязі з падзеямі польска-савецкай вайны. Па-першае, быў зацверджаны новы склад Бюро ЦК Літбела. У яго ўвайшлі «Смілга (старшыня), Алекса, Далецкі, Кнорын, Міцкевіч, Мяснікоў, Уншліхт». Таксама было вырашана «па заняцці Мінска арганізаваць губернскі рэўкам у складзе старшыні Чарвякова, сябра Кнорына, другога сябра, пажадана яўрэя-камуніста», кандыдатуру якога даручалася вызначыць аргбюро ці РВС заходняга фронту сумесна з Бюро ЦК Літбела. Другі аспект беларускага пытання, які абмеркавала палітбюро 25 мая, быў звязаны з прапановай Г. Чычэрына аб «перамовах з белым урадам Беларусі». Наркам тлумачыў неабходнасць перамоў з урадам В. Ластоўскага тым, што той мог «у еўрапейскім маштабе стварыць нам дыпламатычныя непрыемнасці», а таксама трэба было прадухіліць магчымасць для польскага ўрада перацягнуць беларусаў на свой бок [1, с. 140]. Было прынята рашэнне даручыць наркамату замежных спраў «выклікаць з Рэвеля афіцыйнага прадстаўніка беларускага буржуазнага ўрада, які чакаў там адказу». Гэта азначала згоду бальшавікоў пачаць перамовы 3 урадам В. Ластоўскага ${ }^{23}$. Палітбюро 15 чэрвеня прыняло рашэнне пачаць перамовы 3 левымі эсэрамі аб іх удзеле ў вайне з Польшчай [13, с. 121].

У кантэксце пошуку бальшавікамі саюзнікаў супраць Польшчы можна разглядаць і рашэнне палітбюро аб адносінах з Літвой. На пасяджэнні 10 мая абмяркоўвалася праблема ўзаемадзеяння 3 гэтай краінай падчас запланаванага савецкага наступлення на польскім фронце. Камандуючы заходнім фронтам М. Тухачэўскі звярнуўся ў палітбюро з прапановай прадпрыняць намаганні, каб «падштурхнуць літоўскі ўрад да захопу Вільні». Палітбюро даручыла А. Іофе зрабіць папярэднія крокі для рэалізацыі гэтай прапановы ${ }^{24}$. Ход перамоў 3 Літвой аб мірным дагаворы палітбюро абмяркоўвала 25 мая. Нягледзячы на вялікія тэрытарыяльныя патрабаванні літоўцаў, было вырашана не перарываць перамовы з імі ў бліжэйшы час. Гэта звязана са спадзяваннямі выкарыстаць Літву як антыпольскую сілу ${ }^{25}$.

Па меры таго як на фронце Чырвоная армія дабівалася ўсё больш значных поспехаў, на пер-

\footnotetext{
${ }^{16}$ РГАСПИ. Ф. 17. Оп. 3. Д. 75 [Электронный ресурс]. URL: http://sovdoc.rusarchives.ru/sections/government//cards/57339/images (дата обращения: 13.12.2020).

${ }^{17}$ Там же.

${ }_{18}^{18}$ Tам же. Д. 76. URL: http://sovdoc.rusarchives.ru/sections/government//cards/57349/images (дата обращения: 13.12.2020).

${ }^{19}$ Там же. Д. 79. URL: http://sovdoc.rusarchives.ru/sections/government//cards/57425/images (дата обращения: 13.12.2020).

${ }^{20}$ Там же. Д. 82. URL: http://sovdoc.rusarchives.ru/sections/government//cards/13317/childs (дата обращения: 14.12.2020).

${ }^{21}$ Там же. Д. 76. URL: http://sovdoc.rusarchives.ru/sections/government//cards/57349/images (дата обращения: 13.12.2020).

${ }^{22}$ Там же. Д. 74. URL: http://sovdoc.rusarchives.ru/sections/government//cards/13305/childs (дата обращения: 13.12.2020).

${ }^{23}$ Там же. Д. 82. URL: http://sovdoc.rusarchives.ru/sections/government//cards/57463/images (дата обращения: 14.12.2020).

${ }^{24}$ Там же. Д. 76. URL: http://sovdoc.rusarchives.ru/sections/government//cards/57349/images (дата обращения: 13.12.2020).

${ }^{25}$ Там же. Д. 82. URL: http://sovdoc.rusarchives.ru/sections/government//cards/57463/images (дата обращения: 14.12.2020).
} 
шы план у парадку дня палітбюро стаў выходзіць міжнародны аспект польска-савецкай вайны. На пасяджэнні 22 чэрвеня абмяркоўвалася пытанне аб палітыцы ў дачыненні да Усходняй Галіцыі. Палітбюро пагадзілася 3 пазіцыяй Г. Чычэрына, які адзначыў, што, нягледзячы на аптымістычныя заявы галіцыйскіх камуністаў, трэба асцярожна ставіцца да пытання саветызацыі Галіцыі і ўключэння яе «ў межы нашай улады» ${ }^{26}$. У ходзе абмеркавання пытання аб прапанове міру Румыніі 29 чэрвеня была выказана думка, што ад новага польскага ўрада П. Грабскага можна чакаць мірных прапаноў, таму трэба адкласці пытанне міру з Румыніяй ${ }^{27}$.

Ліпеньскі 1920 г. пленум ЦК РКП(б) прыняў рашэнні, якія ставілі задачу саветызацыі Польшчы. Як адзначае расійскі гісторык В. Зубачэўскі, гэта быў паварот савецкага кіраўніцтва ад рэальнай палітыкі да рэвалюцыйнай геапалітыкі [7, с. 170-171]. Дадзены паварот знайшоў сваё адлюстраванне і ў рашэннях палітбюро, якое 23 ліпеня пастанавіла стварыць Польскі рэўкам. На гэтым жа пасяджэнні было абмеркавана пытанне аб пачатку мірных перамоў $з$ Польшчай. Г. Чычэрын мусіў давесці да польскага ўрада, што РСФСР згодная выслаць сваіх упаўнаважаных для сустрэчы 3 прадстаўнікамі Польшчы для пачатку перамоў. Наркаму замежных спраў таксама даручалася сфарміраваць камісію для выпрацоўкі дырэктыў прадстаўнікам фронту для іх першапачатковых перамоў з палякамі і выпрацоўкі «нашых мірных патрабаванняў у дачыненні да Польшчы» ${ }^{28}$. Як бачна, меліся на ўвазе не мірныя «прапановы», а «патрабаванні». Гэта адлюстроўвала падыход бальшавікоў да перагавораў з Польшчай ва ўмовах паспяховага наступлення Чырвонай арміi.

Далей пытанне перагавораў з Польшчай займала адно з цэнтральных месцаў у працы палітбюро. Так, 27 ліпеня быў адобраны план раздзяліць перамовы $з$ Польшчай на «дзве сесіі». Прычым другую сесію, на якой мусілі абмяркоўвацца пытанні папярэдняга міру, а не перамір'я, планавалася пачаць 4 жніўня. Старшынёй савецкай дэлегацыі на перамовах прызначаўся К. Данішэўскі. Палітбюро выказалася за ўключэнне ў праект мірнага дагавора 3 Польшчай пункта аб надзяленні польскіх сялян зямлёй за кошт памешчыкаў ${ }^{29}$. Прадстаўлены праект мірнага дагавора з Польшчай быў зацверджаны Г. Чычэрыным 31 ліпеня. У цэлым яго распрацаваў РВС Рэспублікі. Наркам замежных спраў унёс у праект некаторыя змены. Умовы міру, зацверджаныя палітбюро, павінны былі зрабіць Польшчу без- абароннай перад Савецкай Расіяй, пазбавіць яе суверэнітэту, адкрыць шлях для саветызацыі ${ }^{30}$. За дзень да гэтага для выканання рашэння палітбюро ў Беластоку быў створаны Польскі рэўкам, які сімвалізаваў курс бальшавікоў на саветызацыю Польшчы. Яго стварэнне разам 3 зацверджанымі палітбюро абсалютна непрымальнымі для Польшчы ўмовамі міру ставяць пад сумненне імкненне савецкага кіраўніцтва да мірнага вырашэння польска-савецкага супрацьстаяння ў той момант.

Паражэнне Чырвонай арміі ў Варшаўскай бітве прымусіла палітбюро заняцца выпрацоўкай мер па ўмацаванні заходняга фронту. Гэта пытанне было абмеркавана 19 жніўня. Палітбюро пастанавіла правесці новую мабілізацыю камуністаў, а таксама «прыняць узмоцненыя меры для паскарэння агульнай мабілізацыі беларусаў». Рашэнне аб мабілізацыі сведчыць пра тое, што заходні фронт пачынаў адыходзіць для бальшавікоў на другі план, а галоўную ўвагу яны надавалі барацьбе з Урангелем. Менавіта на паўднёвы фронт планавалася накіраваць 55 \% мабілізаваных камуністаў ${ }^{31}$.

У рашэннях палітбюро ад 25 жніўня ўжо абазначыўся адыход ад выстаўленых Польшчы надзвычай цяжкіх умоў міру. Гэта рашэнне кіраўніцтва бальшавіцкай партыі адлюстроўвае асэнсаванне ім вынікаў Варшаўскай бітвы. У адпаведнасці з прынятым рашэннем К. Данішэўскі павінен быў заявіць палякам не толькі «аб неўльтыматыўнасці» патрабаванняў савецкага боку, але і «аб адмове ад узбраення рабочых» ${ }^{32}$. Палітбюро 26 жніўня заслухала даклад К. Радэка, які быў адкліканы з Мінска ${ }^{33}$. Пасля гэтага на пасяджэнні 1 верасня палітбюро пацвердзіла курс на адыход ад першапачатковай жорсткай пазіцыі на перамовах с Польшчай. Было прынята рашэнне перайсці да палітыкі «згодніцкага міру» $з$ ёй. Для ажыццяўлення новай лініі на мірных перамовах мяняўся склад савецкай дэлегацыі. 3 яго выводзіўся К. Данішэўскі, старшынёй дэлегацыі прызначаўся А. Іофе. Савецкае кіраўніцтва пагадзілася перанесці перамовы ў Рыгу [13, с. 89].

Сам ход перамоў з Польшчай у Рызе не часта станавіууся прадметам абмеркавання палітбюро. Калі ж гэта адбывалася, то закраналася перш за ўсё пытанне аб будучай мяжы. Палітбюро 2 кастрычніка прыняло рашэнне «згадзіцца на лінію, якая аддае Польшчы чыгунку Ліда - Баранавічы, пры ўмове, што мір (і перамір'е) будзе падпісаны ў самы кароткі тэрмін (3 дні прыкладна)» [14, с. 396-397].

\footnotetext{
${ }^{26}$ РГАСПИ. Ф. 17. ОП. 3. Д. 90 [Электронный ресурс]. URL: http://sovdoc.rusarchives.ru/sections/government//cards/57614/images (дата обращения: 14.12.2020).

${ }^{27}$ Там же. Д. 92. URL: http://sovdoc.rusarchives.ru/sections/government//cards/57647 (дата обращения: 14.12.2020).

${ }^{28}$ Там же. Д. 96. URL: http://sovdoc.rusarchives.ru/sections/government//cards/57706/images (дата обращения: 14.12.2020).

${ }^{29}$ Там же. Д. 97. URL: http://sovdoc.rusarchives.ru/sections/government//cards/57710/images (дата обращения: 14.12.2020).

${ }^{30}$ Там же. Д. 99. URL: http://sovdoc.rusarchives.ru/sections/government//cards/57727/images (дата обращения: 14.12.2020).

${ }^{31}$ Там же. Д. 103. URL: http://sovdoc.rusarchives.ru/sections/government//cards/57759/images (дата обращения: 14.12.2020).

${ }^{32}$ Там же. Д. 104. URL: http://sovdoc.rusarchives.ru/sections/government//cards/57784/images (дата обращения: 14.12.2020).

${ }^{33}$ Там же. Д. 105. URL: http://sovdoc.rusarchives.ru/sections/government//cards/57786/images (дата обращения: 15.12.2020).
} 
Да пытання мяжы $з$ Польшчай палітбюро вярнулася 4 кастрычніка. Гэта было звязана 3 тым, што палякі ўдакладнілі сваю пазіцыю адносна лініі граніцы. Быў прыняты падрыхтаваны У. Леніным праект пастановы, якая дазваляла А. Іофе прыняць новыя польскія прапановы пры ўмове, што мір падпішуць на працягу 3-4 дзён [15, с. 145]. Ужо 9 кастрычніка было вырашана дазволіць А. Іофе прыняць дадатковыя патрабаванні палякаў, калі прэлімінарны мір будзе падпісаны неадкладна. Такім чынам, савецкае кіраўніцтва дэманстравала імкненне як мага хучэй заключыць папярэдні мір з Польшчай, каб вызваліць сілы для барацьбы з Урангелем. Для гэтага яно пагаджалася на значныя тэрытарыяльныя ўступкі. 3 другога боку, з матэрыялаў пасяджэння палітбюро вынікае, што савецкае кіраўніцтва на той час яшчэ не адмовілася ад ідэі саветызацыі Польшчы. Пра гэта сведчыць рашэнне «прыняць самыя энергічныя меры для аднаўлення ва ўсім аб'ёме работы Польскага бюро ў фарміруемай польскай Чырвонай арміі ${ }^{34}$. Праўда, 14 кастрычніка гэта сваё рашэнне палітбюро адмяніла ${ }^{35}$.

У пратаколах палітбюро не знайшло адлюстравання пытанне аб удзеле ССРБ у перамовах, у прыватнасці аб ролі А. Чарвякова на мірнай канферэнцыі ў час яго знаходжання ў Рызе.

Палітбюро звярнулася да праблем польскасавецкіх адносін 5 лістапада ў сувязі з набліжэннем пачатку перагавораў аб канчатковых умовах міру. Планавалася «ўзмацніць дыпламатычную і агітацыйную кампанію супраць спроб крайняга мілітарысцкага польскага крыла сарваць мір з Расіяй падтрымкай Пятлюры, Савінкава, Балаховіча». У сувязі з запланаваным аднаўленнем перамоў з палякамі актуалізавалася пытанне аб межах ССРБ. Было прынята рашэнне даручыць наркамнацу і ЦБ КП(б)Б прадставіць прапановы адносна тэрыторыі Беларусі ў ЦК РКП(б) ${ }^{36}$. А 18 лістапада палітбюро зацвердзіла рашэнне нарады па беларускім пытанні ${ }^{37}$. Дадзеная нарада 3 удзелам прадстаўнікоў Савецкай Беларусі адбылася напярэдадні, і на ёй сцвярджалася нясвоечасовасць пастаноўкі пытання аб павелічэнні тэрыторыі ССРБ за кошт вяртання ў яе склад усходніх беларускіх тэрыторый. Пазіцыя Палітбюро ЦК РКП(б) па гэтай праблеме супадала з пазіцыяй ЦБ КП(б)Б, якое на сваім пасяджэнні 11 лістапада 1920 г. пастанавіла «пытанне аб пашырэнні тэрыторыі Беларусі лічыць нясвоечасовым» [16, с. 230].
Палітбюро 24 лістапада абмеркавала пытанне, якое непасрэдна закранала інтарэсы Беларусі. Яно датычылася так званага польскага калідора. Мелася на ўвазе тэрыторыя на паўночным усходзе Беларусі, якая ў адпаведнасці $з$ прэлімінарным дагаворам адыходзіла да Польшчы. У выніку ўстанаўлівалася агульная мяжа з Латвіяй, а Расія адразалася ад Літвы. У бальшавіцкага кіраўніцтва з'явілася ідэя прапанаваць палякам адмовіцца ад калідора ў абмен на тэрытарыяльныя ўступкі ў іншых месцах. Г. Чычэрыну, Л. Троцкаму і Х. Ракоўскаму даручалася падрыхтаваць канкрэтныя прапановы ${ }^{38}$. У далейшым план тэрытарыяльнага абмену быў адхілены.

Прапановы Г. Чычэрына адносна вядзення перамоў з Польшчай палітбюро прыняло 27 лістапада. Было вырашана надаць дэлегацыі ў Рызе паўнамоцтвы самастойна дамовіцца $з$ палякамі аб далейшым ходзе перамоў, а затым і аб даце падпісання мірнага дагавора. Пры гэтым савецкая дэлегацыя павінна была адмовіцца ад абмеркавання польскай прапановы аб гарантыях выканання дагавора ${ }^{39}$. У сярэдзіне снежня ў расійскіх дыпламатычных колах актыўна абмяркоўвалася пытанне аб удзеле прадстаўнікоў ССРБ у перамовах у Рызе [4, с. 31]. Але ў пратаколах пасяджэнняў палітбюро гэта пытанне не адлюстравана.

У вопісе 3 фонду 17 Расійскага дзяржаўнага архіва сацыяльна-палітычнай гісторыі зафіксаваны 121 пратакол за 1920 г. У 26 з іх адлюстраваны пытанні, якія датычыліся польска-савецкай вайны. Лічбы сведчаць пра тое, што і на новым этапе гэтага канфлікту, у тым ліку і ў час падрыхтоўкі прэлімінарнага мірнага дагавора, тэматыка польска-савецкіх адносін не так часта станавілася прадметам абмеркавання на пасяджэннях палітбюро.

На перамовах аб канчатковым міры, якія пачаліся 17 лістапада 1920 г., важнае значэнне набылі пытанні матэрыяльных прэтэнзій Польшчы да Савецкай Расіі. Палітбюро 14 лютага прыняло рашэнне аб уступках Польшчы ў плане замены часткі канцэсій выплатай 15 млн руб. золатам. Таксама палітбюро палічыла неабходным выкупіць маёмасць эвакуіраваных на тэрыторыю Расіі польскіх навучальных устаноў. Найбольш каштоўную культурную маёмасць планавалася не вяртаць Польшчы, а замяніць золатам ${ }^{40}$. Але ў цэлым у пачатку 1921 г. пытанне перамоў у Рызе вельмі рэдка абмяркоўвалася на пасяджэннях палітбюро.

\footnotetext{
${ }^{34}$ РГАСПИ. Ф. 17. ОП. 3. Д. 113 [Электронный ресурс]. URL: http://sovdoc.rusarchives.ru/sections/government//cards/57894/images (дата обращения: 15.12.2020).

${ }^{35}$ Там же. Д. 115. URL: http://sovdoc.rusarchives.ru/sections/government//cards/57917/images (дата обращения: 15.12.2020).

${ }^{36}$ Там же. Д. 120. URL: http://sovdoc.rusarchives.ru/sections/government//cards/57975/images (дата обращения: 15.12.2020).

${ }^{37}$ Там же. Д. 122. URL: http://sovdoc.rusarchives.ru/sections/government//cards/57995/images (дата обращения: 15.12.2020).

${ }^{38}$ Там же. Д. 124. URL: http://sovdoc.rusarchives.ru/sections/government//cards/58004/images (дата обращения: 15.12.2020).

${ }^{39}$ Там же. Д. 108. URL: http://sovdoc.rusarchives.ru/sections/government//cards/14664/images (дата обращения: 16.12.2020).

${ }^{40}$ Там же. Д. 132. URL: http:// http://sovdoc.rusarchives.ru/sections/government//cards/ 58117 (дата обращения: 10.02.2018).
} 


\section{Заключэнне}

Падзеі польска-савецкай вайны і мірных перамоў, якія яе завяршылі, не сталі ключавымі ў дзейнасці Палітбюро ЦК РКП(б). Асабліва выразна гэта праявілася ў 1919 г., калі польскі фронт для бальшавікоў, відавочна, меў другараднае значэнне. У 1920 г. увага да пытанняў, звязаных 3 польскасавецкай вайной, прыкметна ўзрасла. Але ўсё роўна толькі прыкладна пятая частка пратаколаў пасяджэнняў палітбюро ўтрымлівае звесткі аб абмеркаванні ўказанай праблематыкі. Пры гэтым можна адзначыць два ўсплескі актыўнасці палітбюро ў плане разгляду гэтых пытанняў. Першы прыйшоўся на канец красавіка - пачатак мая 1920 г. і быў звязаны $з$ польскім наступленнем на украінскіх землях. У цэнтры ўвагі палітбюро аказаліся пытанні арганізацыі адпору польскаму наступленню. Другі перыяд прыпаў на час мірных перамоў у канцы жніўня - пачатку кастрычніка 1920 г.
3 пункта гледжання тэматыкі пераважалі пытанні вядзення прапагандысцкай работы на польскім фронце, яго кадравага ўмацавання партыйнымі работнікамі і рабочымі. Таксама актуальнымі для палітбюро былі пытанні мірных перамоў з Польшчай. Параўнанне тых рашэнняў, якія па дадзеных пытаннях прымаліся палітбюро, з крокамі савецкай дыпламатыі дазваляе пацвердзіць выснову, што менавіта гэты партыйны орган вызначаў стратэгічную лінію савецкай знешняй палітыкі, а часта прымаў рашэнні і па прыватных, але важных пытаннях польска-савецкіх адносін у разглядаемы час. У пратаколах палітбюро прадстаўлена і беларускае пытанне. Яно разглядаецца вышэйшым кіраўніцтвам бальшавіцкай парты чыста ўтылітарна, як інструмент дасягнення мэт Савецкай Расіі ў яе ваенным і дыпламатычным супрацьстаянні 3 Польшчай.

\section{Бібліяграфічныя спасылкі}

1. Матвеев ГФ. Пилсудский. Москва: Молодая гвардия; 2008. 474 с.

2. Короткова ДА. Белорусские земли в советско-польских отношениях. Разменная карта в противостоянии двух держав. 1918-1921 г2. Москва: Центрполиграф; 2019. 222 с. (Новейшие исследования по истории России).

3. Михутина ИВ. Польско-советская война 1919-1920 г2. Москва: Институт славяноведения и балканистики РАН; 1994. 323 c.

4. Снапкоўскі УЕ. Шлях скрозь стагоддзе: беларуска-польскія адносіны 1918-2017 г2. Мінск: БДУ; 2017.287 с.

5. Лазько РP. Беларуска-савецкія перагаворы 1920 г. W: Michaluk D, redaktor. Biatoruś w XX stuleciu. W kręgu kultury i polityki. Toruń: Uniwersitet Mikolaja Kopernika; 2007. s. 225-337.

6. Бароўская ВМ. Беларускае пытанне на савецка-польскіх перагаворах 1918-1921 г2. Мінск: Беларуская навука; 2017. 269 c.

7. Зубачевский ВА. Политика России в Центрально-Восточной Европе (первая треть ХХ века): геополитический аспект. Омск: Омский государственный педагогический университет; 2018. 396 с.

8. Коваленя АА, Данилович ВВ, Боровская ОН, Вабищевич АН, Валаханович ИА, Великий АФ и др., редакторы. Рижский мир в судьбе белорусского народа. 1921-1953 г2. Книга 1. Минск: Беларуская навука; 2014. 595 с.

9. Снапкоўскі УЕ, рэдактар. Беларусь у палітыщы суседніх і заходніх дзяржаў (1914-1991). Зборнік дакументаў і матэрыялаў. Том 1, частка 2. Мінск: Юніпак; 2008. 540 с.

10. Мельтюхов МИ. 17 сентября 1939. Советско-польские конфликты, 1918-1939. Москва: Вече; 2009. 624 с.

11. Торкунов АВ, Ротфельд АД, редакторы. Белые пятна - черные пятна: сложные вопросы в российско-польских отношениях. Москва: Аспект Пресс; 2010. 823 с.

12. Краснов ВГ, Дайнес ВО. Неизвестный Троцкий. Красный Бонапарт. Документы. Мнения. Размышления. Москва: Олма-Пресс; 2000.510 с.

13. Костюшко ИИ, редактор. Польско-советская война, 1919-1920 (ранее не опубликованные документы и материалы). Часть 1. Москва: Институт славяноведения и балканистики; 1994. 212 с.

14. Амиантов ЮН, Ахапкин ЮА, Логинов ВТ, составители. В. И. Ленин. Неизвестные документы. 1891-1922 г2. Москва: РОССПЭН; 2000. 607 с.

15. Ольшанский ПН. Рижский мир. Из истории борьбы советского правительства за установление мирных отношений с Польшей (конец 1918 - март 1921 г.). Москва: Наука; 1969. 262 с.

16. Снапкоўскі УЕ, рэдактар. Беларусь у палітыщы суседніх і заходніх дзяржаў (1914-1991). Зборнік дакументаў і матэрыялаў. Том 1, частка 2. Мінск: Юніпак; 2008. 394 с.

\section{References}

1. Matveev GF. Pilsudskii [Pilsudski]. Moscow: Molodaya gvardiya; 2008. 474 p. Russian.

2. Korotkova DA. Belorusskie zemli v sovetsko-pol'skikh otnosheniyakh. Razmennaya karta v protivostoyanii dvukh derzhav. 1918-1921 gg. [Belarusian lands in Soviet-Polish relations. A bargaining chip in the confrontation between two powers in 1918-1921]. Moscow: Tsentrpoligraf; 2019. 222 p. (Noveishie issledovaniya po istorii Rossii). Russian.

3. Mikhutina IV. Pol'sko-sovetskaya voina 1919-1920 gg. [Polish-Soviet War, 1919-1920]. Moscow: Institute of Slavic and Balkan Studies, Russian Academy of Sciences; 1994.323 p. Russian.

4. Snapkowski UE. Shljah skroz'stagoddze: belaruska-pol'skija adnosiny 1918-2017 gg. [Way through the centuries: Belarusian-Polish relations, 1918-2017]. Minsk: Belarusian State University; 2017. 287 p. Belarusian. 
5. Laz'ko RR. [Belarusian-Soviet negotiations of 1920]. W: Michaluk D, redaktor. Biatoruś w XX stuleciu. W kręgu kultury i polityki. Toruń: Nicolaus Copernicus University; 2007. p. 225-337. Belarusian.

6. Barowskaja VM. Belaruskae pytanne na savecka-pol'skih peragavorah 1918-1921 gg. [Belarusian question at the SovietPolish negotiations of 1918-1921]. Minsk: Belaruskaja navuka; 2017. 269 p. Belarusian.

7. Zubachevskii VA. Politika Rossii v Tsentral'no-Vostochnoi Evrope (pervaya tret'XX veka): geopoliticheskii aspekt [Russian policy in Central and Eastern Europe (first third of the $20^{\text {th }}$ century): a geopolitical aspect]. Omsk: Omsk State Pedagogical University; 2018. 396 p. Russian.

8. Kovalenya AA, Danilovich VV, Borovskaya ON, Vabishchevich AN, Valakhanovich IA, Velikii AF, et al., editors. Rizhskii mir v sud'be belorusskogo naroda. 1921-1953 gg. Kniga 1 [The peace of Riga in the fate of Belarusian people. 1921-1953. Book 1]. Minsk: Belaruskaja navuka; 2014.593 p. Russian.

9. Snapkouski UE, editor. Belarus' u palitycy susednih i zahodnih dzjarzhaw (1914-1991). Zbornik dakumentaw i matjeryjalaw. Tom 1, chastka 2 [Belarus in the politics of neighboring and western states (1914-1991). A collection of documents and materials. Volume 1, part 2]. Minsk: Junipak; 2008. 540 p. Belarusian.

10. Meltyukhov MI. 17 sentyabrya 1939. Sovetsko-pol'skie konflikty, 1918-1939 [1939 September 17. Soviet-Polish conflicts, 1918-1939]. Moscow: Veche; 2009.624 p. Russian.

11. Torkunov AV, Rotfeld AD, editors. Belye pyatna - chyornye pyatna: slozhnye voprosy v rossiisko-pol'skikh otnosheniyakh [White spots - black spots: complex issues in Russian-Polish relations: scientific publication]. Moscow: Aspekt Press; 2010. 823 p. Russian.

12. Krasnov VG, Dines VO. Neizvestnyi Trotskii. Krasnyi Bonapart. Dokumenty. Mneniya. Razmyshleniya [Unknown Trotsky. Red Bonaparte. Documents. Opinions. Reflections]. Moscow: Olma-Press; 2000. 510 p. Russian.

13. Kostyushko II, editor. Pol'sko-sovetskaya voina, 1919-1920 (ranee ne opublikovannye dokumenty i materialy). Chast' 1 [Polish-Soviet War, 1919-1920 (previously unpublished documents and materials). Part 1]. Moscow: Institute of Slavic and Balkan Studies, Russian Academy of Sciences; 1994. 212 p. Russian.

14. Amiantov YuN, Akhapkin YuA, Loginov VT, compilers. V. I. Lenin. Neizvestnye dokumenty. 1891-1922 gg. [V. I. Lenin. Unknown documents. 1891-1922]. Moscow: ROSSPEN; 2000.607 p. Russian.

15. Olshanskii PN. Rizhskii mir. Iz istorii bor'by sovetskogo pravitel'stva za ustanovlenie mirnykh otnoshenii s Pol'shei (konets 1918 - mart 1921 g.) [Riga Treaty. From the history of the Soviet government's struggle to establish peaceful relations with Poland (late 1918 - March 1921)]. Moscow: Nauka; 1969.262 p. Russian.

16. Snapkouski UE, editor. Belarus' u palitycy susednih i zahodnih dzjarzhaw (1914-1991). Zbornik dakumentaw i matjeryjalaw [Belarus in the politics of neighboring and western states (1914-1991). A collection of documents and materials. Volume 1, part 2]. Minsk: Junipak; 2008. 394 p. Belarusian. 